\title{
DNA flow cytometry of canine mammary tumors: comparative aspects with human breast tumors
}

\author{
[Citometria de fluxo de DNA em tumores mamários da cadela:aspectos comparativos \\ com tumores mamários humano] \\ G.D. Cassali $^{1}$, A. Salvador ${ }^{2}$, C. Freitas $^{2}$, A.P. Dutra ${ }^{1}$, F.C. Schmitt ${ }^{2}$ \\ ${ }^{1}$ Instituto de Ciências Biológicas - UFMG \\ Caixa Postal 486 \\ 31270-901 - Belo Horizonte, MG \\ ${ }^{2}$ Instituto de Patologia e Imunologia Molecular da Universidade do Porto - Porto, Portugal
}

\begin{abstract}
Flow cytometric analysis of DNA content was performed on 28 samples of canine mammary tumors. Nine of them were benign and 19 were malignant. All benign tumors and 11 malignant tumors $(57.9 \%)$ were diploid $(\mathrm{P}<0.05)$. Form the aneuploid tumors, five $(26.3 \%)$ were hyperdiploid, one $(5.3 \%)$ hypodiploid, one (5.3\%) near triploid and one (5.3\%) multiploid. The analysis of the expression of the markers PR and CD31 revealed a significant difference between diploid and aneuploid tumors $(\mathrm{P}<0.05)$. The immunoreactivity of PR was higher in diploid tumors, while the immunoreactivity of CD31 was stronger in aneuploid tumors. No difference between the markers MIB-1, c-erbB2, p53 and Cyclin D1 was observed $(\mathrm{P}>0.05)$. Using the flow cytometry analysis and immunohistochemistry, it was found a close relationship between aneuploidy and malignant character of neoplasias, progesterone receptor (PR) negative immunostaining and higher microvases density. No correlation between DNA content and S phase or immunoreactivity for the markers MIB-1, p53, c-erbB2 and Cyclin D1 was observed.
\end{abstract}

Keywords: dog, breast cancer, neoplasm, DNA flow cytometry, immunohistochemistry

\section{RESUMO}

Análise por citometria de fluxo de DNA foi realizada em 28 amostras de tumores mamários de cadela. Nove eram benignos e 19 malignos, sendo todos os benignos e 11 malignos (57,9\%) diplóides $(P<0,05)$. Dos tumores aneuploides, cinco (26,3\%) eram hiperdiploides, um (5,3\%) hipodiploide, um (5,3\%) triploide e um $(5,3 \%)$ multiploide. A análise dos marcadores de expressão PR e CD31 revelaram significativa diferença entre tumores diploides e aneuploides $(P<0,05)$. A imunorreatividade do $P R$ foi maior em tumores diplóides e a imunoreatividade do CD 31 maior em tumores aneuploides. Para os marcadores MIB-1, c-erbB-2, p53 e Ciclina D1 não foi observada diferença significativa $(P>0,05)$. Pela citometria de fluxo e pela imunoistoquimica verificaram-se uma relação entre aneuploidia e caracteristicas malignas das neoplasias, receptor de progesterona imunoreação negativa e alta densidade de microvascular. Não foi observada correlação entre conteúdo de DNA e a fase S ou imunorreatividade para os marcadores MIB-1, c-erbB-2, p53 e Ciclina D1.

Palavras-chave: cão, câncer de mama, neoplasia, citometria de fluxo de DNA, imunoistoquímica

\section{INTRODUCTION}

The analysis of DNA in human content and percentage of S-phase fraction has been studied in tissues, and has lead to the creation of groups of risk, which could determine type of treatment and prognosis. In women breast cancer, aneuploidy and high S-phase fraction are associated with a poor prognosis and a shorter rate of survival (Wenger and Clark, 1998). The study of DNA ploidy and S-

Recebido em 21 de março de 2007

Aceito em 11 de setembro de 2007

email: cassalig@mono.icb.ufmg.br 
phase related to factors such as ER, PR, c-erbB2, p53 and Ki-67 will be able to be incorporated into a prognostic index that will better reflect the biological diversity of breast cancer and predict its clinical evolution more accurately (Allred et al., 1998).

In veterinary medicine, the use of flow cytometry for analysis of DNA content in mammary tumors is not frequent (Johnson et al., 1981; Hellmén et al., 1988; Rutteman et al., 1991). In two series of mammary cancer cases involving female dogs and human females, the proportion of DNA was found to be similar (Hellmén et al., 1988; Frierson, 1991; Rutteman et al., 1991). However, lower DNA index, referred to as DNA hipoploid, was more common in dogs that in the humans (Hellmén et al., 1988; Rutteman et al., 1991). In a study of mammary female dog tumors (Hellmén et al., 1988), the S-phase analysis and DNA ploidy determined by flow cytometry were not associated with regional lymph nodes involvement.

Using the female dog as a model for the study of human mammary neoplasias, the objectives of this study were to determine, by flow cytometry, the content of DNA and the percentage of Sphase cells in mammary tumors of canine species diagnosed according to the human classification; and to compare the expression of the markers PR, MIB-1, CD-31, p53, c-erbB2 and Cyclin D1 in diploid and aneuploid tumors.

\section{MATERIAL AND METHODS}

Twenty-eight mammary tumors were surgically removed from bitches of different breeds, mixed and pure. The age of the bitches ranged from three to 15 -year-old, with a mean of 8.6 years.

Fresh mammary tumors were immediately placed on ice after surgical removal. The tumors were divided in equal parts and submitted to histological and DNA measurements. Tissue samples for DNA analysis were rapidly frozen in liquid nitrogen ($196^{\circ} \mathrm{C}$ ) and stored at $-70^{\circ} \mathrm{C}$. Tissue samples taken for histology were fixed in $10 \%$ buffered formalin and embedded in paraffin following routine procedures.

Control red blood cells from chickens (CRBC) and lymph nodes (LN) from bitches were used as internal and external standards, respectively. This allowed the determination of the ratio between the normal (diploid) DNA content of bitch and red blood cells (using the mean peak) samples. In human tissue, this ratio is well established between 0.30 and 0.35 .

Nucleic suspensions were stained with propidium iodide to determine the nuclear DNA content. The data was acquired with a coulter EPICS-XL-MCL. The distributions obtained in FL3 (525nm) in a linear 1024 channel histogram were analyzed in a cell cycle analysis program ${ }^{1}$. The DNA index (DI) was defined as the ratio between the modal channel number of the tumor cells and of the internal standard cells (CRCB), in relation to the mean value of the ratio between external standard $\mathrm{LN}$ cells. The range of diploidy was set at two standard deviations (SD) of the mean value of $\mathrm{LN}$ in relation to CRBC. Tumors with DNA values of $1.00 \pm 0.15$ were considered diploid. Tumors with DI less than 0.85 were considered hypodiploid and those presenting DI above 1.15 were considered hyperdiploid. Triploid tumors determined at $1.5 \mathrm{DI}$ and those with more than one abnormal clone were classified as multiploids.

Tumor samples for histological examination (stained by haematoxylin and eosin-HE) were taken from adjacent parts chosen for DNA analysis. The mammary neoplasm was classified according to the human classification (Rosen and Oberman, 1993).

For immunohistochemical staining, by the streptavidin-biotin-peroxidase technique ${ }^{2}, 5 \mu \mathrm{m}$ thick sections were prepared and the antigenic retrieval technique was performed when necessary, according to the recommendation of the manufacturer of the primary antibody (Table 1). The primary antibodies and other reagents were applied using an automatic system of immunohistochemistry ${ }^{3}$. The slides were incubated with the primary antibody for 30 minutes and 10 minutes for each one of the other stages: blocking of the endogenous peroxidase, blocking serum ${ }^{4}$, secondary antibody ${ }^{5}$ streptavidin-biotinperoxidase $^{6}$ and revelation for $\mathrm{DAB}^{7}$. For positive controls, previously tested samples of human breast neoplasms were used and negative controls were obtained by the substitution of primary antibody for normal serum.

${ }^{1}$ Mcycleav Phoenix Flow System, CA.

${ }^{2}$ Ultra vision large volume detection system anti-polyvalent, HRP - ready to use - Lab Vision

${ }^{3}$ Lab Vision Autostainer Model LV-1

${ }^{4}$ Ultra Vison Block, Lab Vison

${ }^{5}$ Biotin Goat, Lab Vision

${ }^{6}$ Streptavidin Peroxidase, Lab Vison

${ }^{7}$ DAB Substrate System, Lab Vision 
DNA flow cytometry of canine...

Table 1. Primary antibodies, characteristics, sources, previous treatment and dilutions tested in the immunohistochemistry study

\begin{tabular}{lcllc}
\multicolumn{1}{c}{ Antibody } & Characteristic & \multicolumn{1}{c}{ Source } & Previous treatment & Dilution \\
\hline PR & Monoclonal, 10 A 9 & Immunotech, France & Retrieval solution & $1: 10$ \\
Ki-67 & Monoclonal, MIB-1 & Immunotech, France & Retrieval solution & $1: 30$ \\
c-erbB2 & Polyclonal & Dako, Denmark & Retrieval solution & $1: 80$ \\
p53 & Polyclonal, CM1 & Novocastra, United & Retrieval solution & $1: 150$ \\
& & Kingdom & Pepsin & $1: 5$ \\
CD31 & Monoclonal & Dako, Denmark & Retrieval solution & $1: 20$ \\
Cyclin D1 & Monoclonal & NeoMarkers, USA & & \\
\hline
\end{tabular}

The Fisher test was used to compare the content of DNA between benign and malignant tumors and to verify difference in the expression of the markers PR, c-erbB-2, p53, and Cyclin D1 between diploid and aneuploid tumors. The Mann and Whitney test was used to verify difference in the expression of the markers MIB-1 and CD31 between diploid and aneuploid tumors.

\section{RESULTS}

From the 28 analyzed tumors, nine were benign and 19 were malignant (Table 2). In the processed material, the mixed tumor was the most frequent benign neoplasia, whilst the most frequent malignant tumor was the invasive ductal carcinoma (NOS). All (100.0\%) benign tumors and 11 out of 19 malignant tumors $(57.9 \%)$ were diploid $(\mathrm{P}<0.05)$ (Fig. 2, A and B). Of the aneuploid tumors, five
(26.3\%) were hyperdiploid, one (5.3\%) was hypodiploid, one $(5.3 \%)$ was near triploid and one $(5.3 \%)$ was multiploid.

The S-phase fraction was higher in malignant tumors than in benign tumors. Among the malignant tumors, the S-phase was higher in the aneuploid type, although the difference was not significant (Table 3).

Analysis of the expression markers PR and CD31 revealed a significant difference between diploid and aneuploid tumors $(\mathrm{P}<0.05)$ (Table 4 and 5). Immunoreactivity of $\mathrm{PR}$ was higher in diploid tumors, while immunoreactivity of CD31 was stronger in aneuploid tumors. However, for the markers MIB-1, c-erbB2, p53, and Cyclin D1, low difference was observed $(\mathrm{P}>0.05)$.

Table 2. DNA ploidy status in 28 canine mammary tumors in relation to their histological type

\begin{tabular}{lccc}
\hline Diagnosis & Number of tumors & Diploid & Aneuploid \\
\hline Benign & 9 & & - \\
Mixed tumor & 7 & 7 & - \\
Adenomyoepithelioma & 1 & 1 & - \\
Ductal adenoma & 1 & 1 & \\
Malignant & 19 & & 4 \\
Invasive ductal carcinoma & 7 & 3 & 2 \\
Carcinoma with metaplasia & 4 & 2 & - \\
Squamous cell carcinoma & 2 & 2 & 1 \\
Invasive papillary carcinoma & 2 & 1 & 1 \\
Osteossarcoma & 2 & 1 & - \\
Invasive micropapillary carcinoma & 1 & 1 & - \\
Secretory carcinoma & 1 & 1 & 8 \\
Total & 28 & 20 & \\
\hline
\end{tabular}

Table 3. S phase value of 28 canine mammary tumors in relation to their DNA ploidy status

\begin{tabular}{lccc}
\hline \multicolumn{1}{c}{ Diagnosis } & Number of Tumors & S phase (\%) Mean & S phase (\%) Range \\
\hline Benign & 9 & 6.37 & $2.0-24.4$ \\
Diploid & 9 & 6.37 & $2.0-24.4$ \\
Aneuploid & - & - & - \\
& & & \\
Malignant & $\underline{9}$ & 11.44 & $2.1-46.6$ \\
Diploid & 11 & 8.75 & $2.1-21.3$ \\
Aneuploid & 8 & 15.13 & $2.6-46.6$ \\
\hline
\end{tabular}

No differences between $\mathrm{S}$ phase mean and $\mathrm{S}$ phase range were observed $(\mathrm{P}>0.05)$. 
Table 4. Expression of the markers PR, p53, c-erbB2, and Ciclin D1 in diploid and aneuploid canine mammary tumors

\begin{tabular}{lcc} 
Marker & $\begin{array}{c}\text { Diploid } \\
\text { Positive/Negative }\end{array}$ & $\begin{array}{c}\text { Aneuploid } \\
\text { Positive/Negative }\end{array}$ \\
\hline PR & $12 / 4 \mathrm{a}$ & $2 / 6 \mathrm{~b}$ \\
p53 & $8 / 8 \mathrm{a}$ & $4 / 4 \mathrm{a}$ \\
c-erbB2 & $9 / 7 \mathrm{a}$ & $4 / 4 \mathrm{a}$ \\
Ciclin D1 & $5 / 11 \mathrm{a}$ & $5 / 3 \mathrm{a}$ \\
\hline
\end{tabular}

Equal letters in the same row indicate no significant difference $(\mathrm{P}>0.05)$.
Table 5. Expression of the markers MIB-1 and CD31 in diploid and aneuploid canine mammary tumors

\begin{tabular}{lcc}
\hline \multicolumn{1}{c}{ Marker } & Diploid Mean & Aneuploid Mean \\
\hline MIB-1 & $18.06 \pm 14.11 \mathrm{a}$ & $28.25 \pm 18.1 \mathrm{a}$ \\
CD31 & $43.39 \pm 24.63 \mathrm{a}$ & $91.83 \pm 53.21 \mathrm{~b}$ \\
\hline
\end{tabular}

Equal letters in the same row indicate no significant difference $(\mathrm{P}<0,05)$.

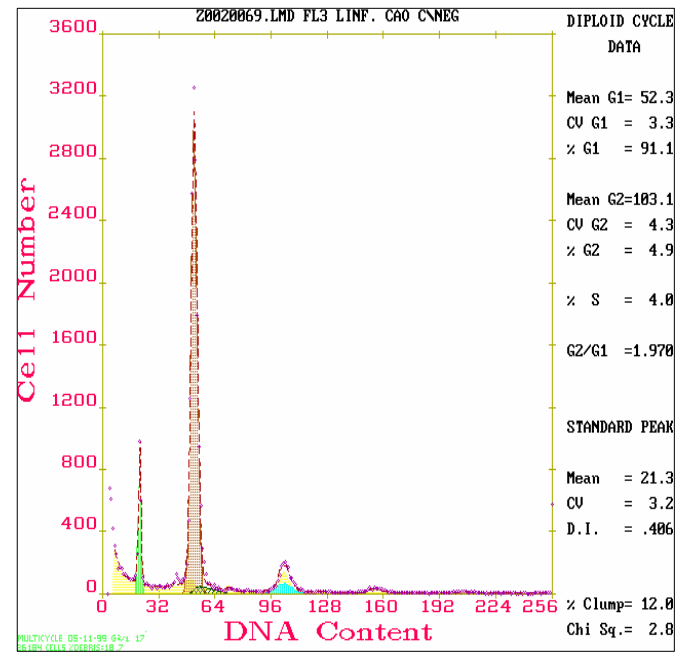

Figure 1. Female dog. Lymph node. Histogram of DNA (flow cytometry). Diploid external control (lymphocytes).

(A)

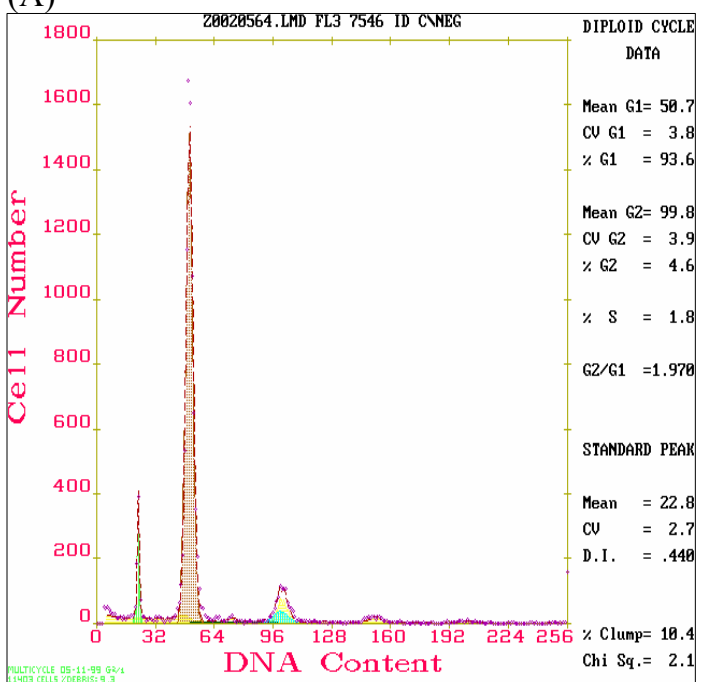

(B)

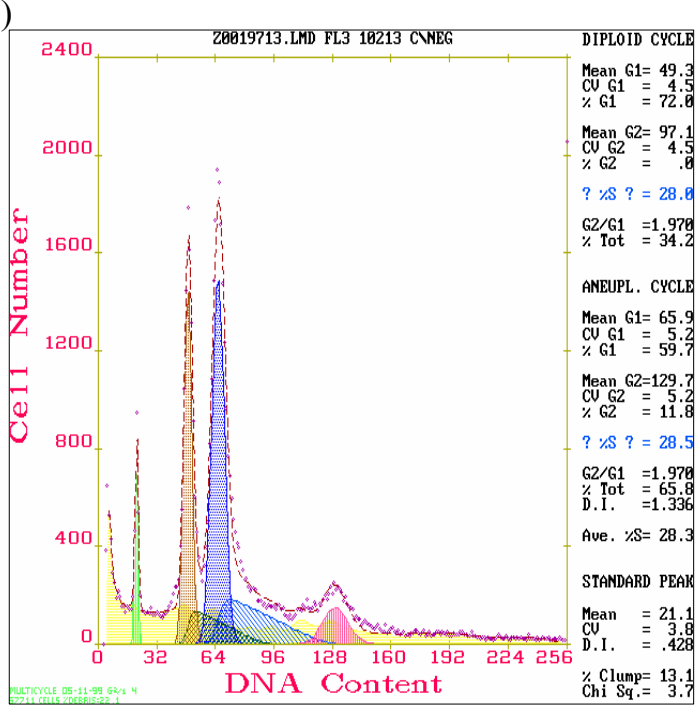

Figure 2. Female dog. Mammary gland tumors. Histogram of DNA (flow cytometry). Secretory carcinoma - diploid. (B) Osteossarcoma - aneuploid (A). 


\section{DISCUSSION}

In this study, $42 \%$ of malignant tumors were aneuploid, and $100 \%$ of benign were diploid. Other authors found higher incidence of aneuploid among malignant canine mammary tumors: 48.5\% (Pérez - Alenza, 1995), 52\% (Rutteman et al., 1988; Hellmén et al., 1993). High incidence $(63 \%)$ was reported for human breast cancer, based on data compiled from 56 studies (Frierson, 1991). In one flow cytometric study of paraffin wax-embedded tissue, the incidence of aneuploidy in canine malignant mammary tumors was $31 \%$, and all the 14 benign tumors were diploid (Scanziani, 1991). However, the degree of deviation in the DNA index of many aneuploid mammary tumors in dogs is relatively low compared with the deviation in human breast cancer (Hellmén et al, 1988; Rutteman et al, 1988), which increases the risk of misclassification of paraffin waxembedded dog tumors (Rutteman and Cornelisse, 1991).

On the other hand, the incidence for aneuploidy described in literature in benign proliferative mammary lesions of dogs has been remarkably higher (14.3\%, Pérez Alenza et al., 1995; 17.4\%, Rutteman et al., 1988; 26\%, Rutteman and Cornelisse, 1991), than the incidence in human species $(0.65 \%$, Beerman, 1991). The same criteria have been used for humans, for methodology and classification, and probably obtained similar results to those observed in human samples.

It was also obtained the ratio between dog normal cells and CRBC. This may contribute for further comparative pathology studies, and also establish an easier internal control for the determination of DNA content (Hellmén et al., 1988).

Only one hypodiploid clone $(5.3 \%)$ was found out of 19 malignant tumors. Other studies have described a higher frequency of hipoploid tumors (Hellmén et al., 1988; Rutteman et al., 1988; Pérez Alenza et al., 1995). These results are in accordance with those by Frierson (1991), on human breast cancer, in which the mean value was $2 \%$.

The S-phase was higher in aneuploid than in diploid malignant tumors. A similar result was observed in dog (Hellmén et al., 1993; Pérez Alenza et al., 1995) and man (Frierson, 1991). The S-phase of malignant tumors was higher than benign tumors, in spite of not being verified a significant difference, such finding is limited due to the small number of cases. This tendency was confirmed by the highest expression of MIB-1 in aneuploid tumors.

This study demonstrates a difference in immunostaining reactivity for PR between diploid and aneuploid tumors. These results are in agreement with the reports of others authors who showed a correlation between aneuploid tumors and negative estrogen receptors in the women breast cancer (Wenger and Clark, 1998; Leers and Nap, 2001; Tsutsui et al., 2002). However, Rutteman et al. (1988), studying steroid receptors in female dog tumors, did not observe such correlation.

It was also found higher microvase density by immunoreactivity with CD 31 in aneuploid tumors. According to Bosari et al. (1992), the highest microvases proliferation can be associated with tumor aggressiveness. However, in human cases, no correlation between angiogenesis and DNA ploidy was found (Marinho et al., 1997).

In this study, it was observed a tendency for higher expression of markers MIB-1 and Cyclin D1, in aneuploid tumors. In the veterinary medicine literature, no reports correlating these markers with DNA ploidy were found. Similarly, in women breast cancer, a higher expression of markers Cyclin D1 (Collechi et al., 1999) and MIB-1 (Querzoli et al., 1996; Massod et al., 1998) were described in aneuploid tumors.

In this study, using flow cytometry analysis and immunohistochemistry, a close relationship between aneuploidy and malignant character of neoplasia, PR negative immunostaining and high positivity to marker CD31 were found. However, no correlations between DNA content and S phase or immunoreactivity for the markers MIB1, p53, c-erbB2, and Cyclin D1 were observed.

These findings point toward a biological change of tumor properties during the oncogenesis process. The aneuploidy which accompanied the changes in cell differentiation was associated 
with negative progesterone receptors and higher microvase density.

\section{ACKNOWLEDGMENTS}

We are grateful to CAPES/GRICES and CNPq for financial support.

\section{REFERENCES}

ALLRED, D.C.; HARVEY, J.M.; BERARDO, M. et al. Prognostic and predictive factors in breast cancer by immunohistochemical analysis. Mod. Pathol., v.11, p.155-168, 1998.

BEERMAN, H. Analytical cytology of breast cancer. 1991. Thesis (PhD) - University of Leiden, Netherlands.

BOSARI, S.; LEE, A.K.; DE LELLIS, R.A. et al. Microvessel quantitation and prognosis in invasive breast carcinoma. Hum. Pathol., v.23, p.755-761, 1992

COLLECHI, P.; PASSONI, A.; ROCCHETTA, M. et al. Cyclin-D1 expression in node positive $(\mathrm{N}+)$ and node-negative $(\mathrm{N}-)$ infiltrating human mammary carcinomas. Inst. J. Cancer, v.84, p.139-144, 1999.

FRIERSON, H.F. Ploidy analysis and S-phase fraction determination by flow cytometry of invasive adenocarcinomas of the breast. Am. J. Surg. Pathol., v.15, p.358-367, 1991.

HELLMÉN, E.; BERGSTRÖM, R.; HOLMBERG, L. et al. Prognostic factors in canine mammary tumors: a multivariate study of 202 consecutive cases. Vet Pathol., v.30, p.2027,1993

HELLMÉN, E.; LINDGREN, A; LINELL, F. et al. Comparison of histology and clinical variables to DNA ploidy in canine mammary tumors. Vet. Pathol., v.25, p.219-226, 1988.

JOHNSON, T.S.; RAJU, M.R.; GILTINAN, R.K. et al. Ploidy and DNA distribution analysis of spontaneous dog tumors by flow cytometry. Cancer Res., v.41, p.3005-3009, 1981.

LEERS, M.P.; NAP, M. Steroid receptor heterogeneity in relation to DNA index in breast cancer: a multiparameter flow cytometric approach on paraffin-embedded tumor samples. Breast J., v.7, p.249-259, 2001.

MARINHO, A.; SOARES, R.; FERRO, J. et al. Angiogenesis in breast cancer is related to age but not other prognostic parameters. Pathol. Res. Pract., v.193, p.267-273, 1997.

MASOOD, S.; BUI, M.M.; LU, L. Comparison of proliferation activity in breast carcinoma by flow cytometry analysis of S-phase and quantitative analysis of MIB-1. Ann. Clin. Lab. Sci., v.28, p.315-323, 1998.

PÉREZ ALENZA, M.D.; RUTTEMAN, G.R.; KUIPERS-DIJKSHOORN, N.J. et al. DNA flow cytometry of canine mammary tumours: the relationship of DNA ploidy and S-phase fraction to clinical and histological features. Res. Vet. Sci., v.58, p.238-243, 1995.

QUERZOLI, P.; ALBONICO, G.; FERRETTI, $\mathrm{S}$. et al. MIB-1 proliferative activity in invasive breast cancer measured by image analysis. $J$. Clin. Pathol., v.49, p.926-930, 1996.

ROSEN, P.P.; OBERMAN, H.A. Tumors of the mammary gland. In: Armed Forces Institute of Pathology, Washington, 1993. 390p.

RUTTEMAN, G. R.; CORNELISSE, C. J. Flow cytometric analysis of nuclear DNA content in solid tumors. Vet. Pathol., v.28, p.453-456, 1991.

RUTTEMAN, G.R.; CORNELISSE， C.J.; DIJKSHOORN, N.J. et al. Flow cytometric analysis of DNA ploidy in canine mammary tumors. Cancer Res., v.48, p.3411-3417, 1988.

SCANZIANI, E.; CANIATTI, M.; SEN, S. et al. Flow cytometric analysis of cellular DNA content in paraffin wax-embedded specimens of canine mammary tumours. J. Comp. Pathol., v.105, p.75-82, 1991

TSUTSUI, S.; OHNO, S.; MURAKAMI, S. et al. DNA aneuploidy in relation to the combination of analysis of estrogen receptor, progesterone receptor, p53 protein and epidermal growth factor receptor in 498 breast cancers. Oncology, v.63, p.48-55, 2002.

WENGER, C.R.; CLARK, G.M. S-phase fraction and breast cancer - a decade of experience. Breast Cancer Res. Treat., v.51, p.255-265, 1998. 